\title{
USING MICROWAVE TECHNIQUE TO TREAT CONTAMINATED DRILL CUTTINGS
}

\author{
${ }^{1}$ Ahmed A. Khudhair ${ }^{*}$ and ${ }^{1}$ Ayad A. Al-Haleem \\ ${ }^{1}$ Department of Petroleum, College of Engineering, University of Baghdad, Baghdad, Iraq \\ *Email: ahmed.a.khdair@gmail.com \\ Received: 18 July 2020; accepted: 18 September 2020
}

\begin{abstract}
Drilling waste is a vital and persistent problem found in the petroleum industry which is mainly related to drilling and oil production. When drilling fluids ruminants are discharged on the ground, human health is affected by the toxic of oil contamination and the chemicals of liquid fraction ruin organisms functional and contaminate the groundwater as a result of seeping. A microwave technique was used to treat the remain drill cuttings resulting from drilling fluid. Whereas amounts of drill cuttings were taken from the southern Rumaila oilfields, prepared for testing and fixed with $100 \mathrm{gm}$ per sample and contaminated with two types of crude oil, one from the southern Rumaila oilfields with Specific gravity of 0.882 and the other crude oil from the eastern Baghdad oilfield of Specific gravity 0.924. The concentrations of $7.5 \%, 10 \%, 12.5 \%$ and $15 \% \mathrm{w} / \mathrm{w}$ in mass was chosen to be the pollution percentage. Samples were treated in the microwave with different power applied of 180, 540, and 900 watt and a time period of 50 minutes is divided into 5 parts for analysis 0, 10, 20,30 and 50 min. the purpose of this study was trying to reach the zero-discharge concept treatment or near. It was found that the results of 22 sample reached below $1 \% \mathrm{w} / \mathrm{w}$ in mass, except for two samples of 180-watt power applied and oil contamination of $15 \% \mathrm{w} / \mathrm{w}$ in mass they reached about $1.5-1 \% w / w$ in mass. The results show a great declination in oil contamination even with highest pollution with lower power applied.
\end{abstract}

Keywords: Drill cuttings waste; Microwave treatment; oil Contamination; Oil-based mud treatment

\section{INTRODUCTION}

Waste disposal operations from the oil and gas industry, unexpected accident leakage, or improperly disposing of drilling waste, have quite serious consequences for the human health and the environment in general. When contaminated drill cuttings are removed with the remains drilling fluids, especially with oil-based mud (OBM), the chemical fractions of liquids begin to 
seep into the ground, causing the elimination of existing organisms and contaminated groundwater (Siddique et al., 2017). Since the disposal of drilling waste had become a global problem that causes escalating anxiety, especially for researchers and oil companies, due to the multiple negative impacts on public and environmental health (Moseley, 1983), Iraq cannot be an exception in this manner. The US Environmental Protection Agency (US EPA) stated that discharged cuttings cannot be greater than $6.9 \%$ by mass for the organic pollution of synthetic fluid adhered (Santos et al., 2018). Besides, In the United Kingdom and European Union, the discharge regulation compliance obliges a limit of less than $5.5 \%$ of organic content and $1 \%$ of oil on cuttings (Jafarinejad, 2017). Drilling waste which produced by the exploration and production industry is coming in the second place of international ranking for the largest volume of waste produced (Haut et al., 2007). The waste disposal problem has become an important point in achieving a good environmental management system. In general, contamination of drilling fluids with drill cuttings waste is an inevitable result of successful drilling operations; therefore, drill cuttings waste accumulation ought to go through the treatment and disposal option after all. In that situation of the drill cuttings that need to be handled earlier to disposal, there are numerous feasible selections including land-farming, bioremediation, solidification, thermal desorption, stabilization and cuttings re-injection (Growcock et al., 2002), etc. Land reclamation is a regularly utilized bioremediation strategy in which the oil-contaminated drill cuttings are applied to the land where evaporation synchronically with the natural organisms of the soil combine to diminish the pollution of the waste (Zimmerman and Robert, 1991), (Chaineau et al., 1996). Among of these ways, microwave drying is one of the modern technologies used industrially and at home, which showed effective results in its practical applications and brought about an ever-increasing change in relation to drying various materials (Omran et al., 2014). The treatment levels accomplished by the microwave drying process were significantly greater than those used in the solid control system (Robinson et al., 2009) (Robinson et al., 2010). The microwave technique is a treatment method for handling waste of many kinds and has multiple advantages. It is also easy to use and fast to accomplish, as well as it can be controlled remotely and with great flexibility. Furthermore, the microwave can reach the required temperature in less than $1 \%$ of the time required by traditional heating methods. Besides, the microwave technique is preferred as it considered to be a source of clean energy (Haghi and Amanifard, 2008) (FernAndez et al., 2011). The application of a microwave oven, which can be used on-site, is one of the high gain methods in terms of the process of greatly reducing pollution levels that meet the legal requirements for treating and storing waste, unlike the usual methods whose results are almost satisfactory. The approach used in this study 
tries to reach zero discharge concept or close, for oil contamination in drilling waste of Rumaila oilfield, by using microwave treatment technique.

\section{MATERIALS AND METHODS}

\section{Drill Cuttings}

The drill Cuttings which have been used in this study, were collected from Rumaila oilfield pits. The Rumaila is the biggest oilfield in Iraq (Al-Jaberi and Al-Mayyahi, 2018). Moreover, Rumaila oilfield could be the $9^{\text {th }}$ biggest oilfield in the world (Al-Ali et al., 2020). The waste drill cuttings obtained from Rumaila waste pit were resulted from the formation which has been drilled and the remain of separating water-based mud. As a result, the drill cuttings are needed to be prepared before the treatment. Therefore, the drill cuttings had been treated in microwave oven by applying maximum power applied for 24 hours in order to get rid of the water and organic contents. Then, pure samples were taken from the drill cuttings and fixed at $100 \mathrm{gm}$ weight and crushed to have a size of grain $(5-10 \mathrm{~mm})$ for each sample (Silva et al., 2019) and (Tinmaz et al., 2019).

\section{Drilling Fluid}

Hydrocarbon is intricate compounds of many composites. These composites include branched, monocyclic, straight chained, cyclic and polycyclic aromatic hydrocarbons. Various oils and petroleum-associated products have variety grade of toxicity. Ordinarily, oils with longer carbon bonds and with more rings of benzene have higher grades of toxicity. Generally, Benzene is the hydrocarbon composite with the highest grade of toxicity. Followed by toluene, methylbenzene and xylenes in toxicity gradient. Compounds with the lowest toxicity level are motor oil and crude oil (Montagnolli, 2015 and Di Toro, 2007).

In spite of different grade of toxicity amongst various types of oil, all hydrocarbon shapes in nature have diverse effects on human health and the ecosystem. Semi-volatile organic carbons (SVOCs) (i.e. PAHs) have accumulative impact on the nervous system resulting to fatigue, dizziness, amnesia, and headache. In serious cases, epoxide compounds with carcinogenic and mutagenic and characteristic are generated by PAH metabolism in the human body which effect the blood, kidney, lungs, spleen, liver, skin and immune (Ubani and Onyejekwe, 2013). Furthermore, Crude oil evaporating lead to birth defects. Also, Benzene, that exists in crude oil and gasoline, is familiar to cause leukemia in humans as well as lower the white blood cell count. Researches have related benzene exposure, in range of just parts per billion (PPB), to Hodgkin's lymphoma, terminal leukemia and immune system diseases after 5-15 years of exposure (Kirkeleit et al., 2006; Prasad and Kumari, 1987). The most three 
common sources of this contamination are the using of OBM drilling fluid, using the synthesis drilling base mud fluid and or drilling in the hydrocarbon reservoir zone. Two types of crude oil were taken; The first type of the crude oil was taken from the reservoir of Rumaila oilfield in Basra and the other one was taken from Eastern Baghdad oilfield in Baghdad after the treatment from the impurities. The hydrocarbon's specific gravity of Rumaila oilfield was measured 0.882. Whereas the hydrocarbon's specific gravity of Eastern of Baghdad oilfield was 0.924 .

\section{Microwave}

A microwave device is composed of a high-voltage energy source, which transfers power to the magnetron; a cavity magnetron, which transforms into microwave radiation from high-voltage electric power; the magnetron is connected to a high-voltage capacitor; a magnetron control circuit which connected commonly with a microcontroller; a short waveguide to direct microwave energy to the cooking chamber from the magnetron; a metal cooking chamber; a control panel (Zitzewitz, 2011). The Specifications of microwave device model were GMO330 with inputs of $50 \mathrm{~Hz}$ and 1400-Watt, output of $2450 \mathrm{~Hz}$, maximum of 900 Watt and selective power applied and GRILL of 1100 Watt. Microwave treating can contribute a more expeditious processing rate than traditional heating methods because of microwave's volumetric heating impacts (Abdulbari et al., 2011). the energy of microwave is utilized the electromagnetic field in order to penetrate the substances instantly within the molecular reaction. all individual components of the substance being heated independently by microwave heating, while the thermal conductivity of a substance restricts the interior temperature diffusion of it subject to conventional heating. Consequently, heating rates, employing microwaves, can usually be reduced to less than $1 \%$ of those required practicing conventional heating routines. The frequency of microwave ranges $300 \mathrm{MHz}-300 \mathrm{GHz}$. while the practical applicability of microwave heating industrially is normally operated a range $900 \mathrm{MHz}-2.45$ GHz (Appleton et al., 2005 and Hu et al., 2013). The application of a microwave oven is one of the high gain methods in terms of the process of greatly reducing pollution levels that meet the legal requirements for treating and storing waste, traditional drying and evaporating contamination technique whose results are almost satisfactory. Moreover, heating the substances in a microwave device decreases the production of carcinogenic char. (Regier et al., 2016; Proestos, and Komaitis, 2008).

\section{Experimental Work}

Microwave technique can contribute a more active processing speed than traditional heating methods, because of its volumetric heating influences. Within molecular interactions, the 
microwave power can directly break through the substances with the electromagnetic field (Tinmaz et al., 2019). the thermic conductivity of a substance limits the internal temperature diffusion for conventional heating, whilst Microwave heating can lead in all individual components of the body being heated independently. Consequently, heating times employing microwaves can regularly be reduced to less than $1 \%$ of those required employing conventional heating methods (Junior, 2015). Three parameters were taken; the power applied was 180, 540 and 900 Watt, the hydrocarbon concertation was $7.5 \%, 10 \%, 12.5 \%$ and $15 \% \mathrm{w} / \mathrm{w}$ in mass, which is $8.11,11.11,14.29$ and $17.65 \mathrm{gm}$ of hydrocarbon, for two kinds of hydrocarbon as mentioned before with specific gravity $(0.882$ and 0.924$)$. The period of treatment was $50 \mathrm{~min}$ dividing by 5 times which is $0,10,20,30$ and $50 \mathrm{~min}$. The sample of $100 \mathrm{gm}$ of drill cutting contaminated with oil weighted in glass container. Then the treatment starts by inserting the container in chamber.

\section{Analytical Method}

The process of analyses to monitor the progress of decreasing in the oil contamination was checked using the electronic balance instrument. At first, a glass container weight was calculated. Then, the polluted drill cuttings were weighted and since the drill cuttings weight is fixed at $100 \mathrm{gm}$, the formula that represented the remain of hydrocarbon concentration is as follow:

$$
\mathrm{W}_{\text {hyd }}=\mathrm{W}_{t(n)}-\left(\mathrm{W}_{\text {hydi }}+\mathrm{W}_{c o n}+\mathrm{W}_{c u t}\right)
$$

Where:

$\mathrm{W}_{\text {hyd }}=$ The remain weight of hydrocarbon after any period of time in gm unit.

$\mathrm{W}_{\text {hydi }}=$ The initial weight of hydrocarbon before treatment in gm unit .

$\mathrm{W}_{\text {con }}=$ weight of glass container in gm unit.

$\mathrm{W}_{\text {cut }}=$ Weight of fixed drill cuttings which is $100 \mathrm{gm}$.

$\mathrm{W}_{t(n)}=$ The total weight at any period of hydrocarbon contamination, drill cuttings of $100 \mathrm{gm}$ and their container in gm unit.

\section{RESULTS}

It appears from Tables 1, 2 and 3 below, that the concentrations decreased with the increase of time. 
Table 1. Treating drill cutting with power applied 180 Watt

\begin{tabular}{|c|c|c|c|c|c|c|c|c|}
\hline $\begin{array}{c}\text { Time } \\
\text { (min) }\end{array}$ & \multicolumn{3}{|c|}{ Concentration of Sp. Gr. 0.882 } & \multicolumn{3}{c|}{ Concentration of Sp. Gr. 0.924 } \\
\hline 0 & $7.5 \%$ & $10 \%$ & $12.5 \%$ & $15 \%$ & $7.5 \%$ & $10 \%$ & $12.5 \%$ & $15 \%$ \\
\hline 10 & $5.34 \%$ & $9.12 \%$ & $12.32 \%$ & $14.79 \%$ & $5.98 \%$ & $9.21 \%$ & $12.36 \%$ & $14.83 \%$ \\
\hline 20 & $3.25 \%$ & $7.25 \%$ & $11.15 \%$ & $13.50 \%$ & $3.11 \%$ & $7.01 \%$ & $10.56 \%$ & $13.62 \%$ \\
\hline 30 & $0.92 \%$ & $1.78 \%$ & $6.23 \%$ & $10.71 \%$ & $0.88 \%$ & $1.47 \%$ & $5.94 \%$ & $9.23 \%$ \\
\hline 50 & $0.32 \%$ & $0.62 \%$ & $0.81 \%$ & $1.41 \%$ & $0.21 \%$ & $0.49 \%$ & $0.69 \%$ & $1.01 \%$ \\
\hline
\end{tabular}

Table 2. Treating drill cutting with power applied 540 Watt

\begin{tabular}{|c|c|c|c|c|c|c|c|c|}
\hline $\begin{array}{c}\text { Time } \\
\text { (min) }\end{array}$ & \multicolumn{3}{|c|}{ Concentration of Sp. Gr. 0.882 } & \multicolumn{3}{c|}{ Concentration of Sp. Gr. 0.924 } \\
\hline 0 & $7.5 \%$ & $10 \%$ & $12.5 \%$ & $15 \%$ & $7.5 \%$ & $10 \%$ & $12.5 \%$ & $15 \%$ \\
\hline 10 & $4.61 \%$ & $8.79 \%$ & $11.91 \%$ & $14.55 \%$ & $4.09 \%$ & $8.13 \%$ & $11.51 \%$ & $14.68 \%$ \\
\hline 20 & $0.87 \%$ & $1.57 \%$ & $6.02 \%$ & $11.58 \%$ & $0.71 \%$ & $1.34 \%$ & $5.39 \%$ & $11.07 \%$ \\
\hline 30 & $0.61 \%$ & $1.02 \%$ & $1.76 \%$ & $7.32 \%$ & $0.54 \%$ & $0.94 \%$ & $1.56 \%$ & $7.19 \%$ \\
\hline 50 & $0.30 \%$ & $0.47 \%$ & $0.71 \%$ & $0.91 \%$ & $0.19 \%$ & $0.41 \%$ & $0.61 \%$ & $0.83 \%$ \\
\hline
\end{tabular}

Table 3. Treating drill cutting with power applied 900 Watt

\begin{tabular}{|c|c|c|c|c|c|c|c|c|}
\hline $\begin{array}{c}\text { Time } \\
(\mathrm{min})\end{array}$ & \multicolumn{3}{|c|}{ Concentration of Sp. Gr. 0.882 } & \multicolumn{3}{c|}{ Concentration of Sp. Gr. 0.924 } \\
\hline 0 & $7.5 \%$ & $10 \%$ & $12.5 \%$ & $15 \%$ & $7.5 \%$ & $10 \%$ & $12.5 \%$ & $15 \%$ \\
\hline 10 & $1.50 \%$ & $2.80 \%$ & $10.05 \%$ & $13.90 \%$ & $1.32 \%$ & $2.61 \%$ & $11.26 \%$ & $14.25 \%$ \\
\hline 20 & $0.65 \%$ & $0.94 \%$ & $1.77 \%$ & $10.10 \%$ & $0.61 \%$ & $0.93 \%$ & $1.51 \%$ & $11.02 \%$ \\
\hline 30 & $0.55 \%$ & $0.62 \%$ & $0.89 \%$ & $1.30 \%$ & $0.49 \%$ & $0.53 \%$ & $0.81 \%$ & $1.23 \%$ \\
\hline 50 & $0.28 \%$ & $0.35 \%$ & $0.49 \%$ & $0.66 \%$ & $0.20 \%$ & $0.31 \%$ & $0.43 \%$ & $0.56 \%$ \\
\hline
\end{tabular}

It appears from the table that the concentrations decreased with the increase of time, and this shows that the relation between time and the decrease in concentrations is a direct correlation. Also, the reduction in the concentration levels increased with raising the power applied from 180, 540 to $900 \mathrm{Watt}$. The pollution declination, even for $15 \% \mathrm{w} / \mathrm{w}$ in mass, in 22 samples reached below $1 \%$ and only two of them was below $1.5 \%$ in the end of treatment. Furthermore, Tables show that the best result was for $900 \mathrm{Watt}$, for concentration of $7.5 \% \mathrm{w} / \mathrm{W}$ in mass. whilst the highest concentration after treatment was $1.41 \% \mathrm{w} / \mathrm{w}$ in mass for $180 \mathrm{Watt}$ for $15 \% \mathrm{w} / \mathrm{w}$ initial concentration.

\section{DISCUSSIONS}

Figures below were made to discuss the results depending on the ratio of oil contamination weight loss for comparison purpose as it shown in formula below.

$$
\frac{X_{n}}{\mathrm{X}}=\frac{W_{\text {hyd }}}{\mathrm{W}_{\text {hydi }}}
$$




\section{Iraqi Geological Journal Khudhair and Al-Haleem 53 (2D), 2020: 42-52}

Where:

$\left(\frac{X_{n}}{X}\right)=$ The ratio of the oil contamination weight at any period to its initial where $\left(0 \leq \frac{X_{n}}{X} \leq 1\right)$ Dimensionless.

Figs. 1, 2, 3 and 4 show that when the power applied is increased, the concentration dropping increase in which similar conclusion was stated by Tinmaz et al. (2019), fluid reduction increased and drying time was shortened by raising microwave power in which microwave ovens can transfer energy to the entire substance, as the energy affects the internal structure. This will cause of higher energy acting on the internal structure if the power applied increased. Moreover, when concentration of the hydrocarbon in drill cuttings is little, the treatment reaches to less than $1 \%$ much faster. Also the microwave penetration needed more time when the concentration of oil contamination in drill cutting is increase in which as it was confirmed by Tinmaz et al. (2019) for using water based drill cutting remnant contaminated with oil from production zone and Junior (2015) for using n-Paraffin based mud remnant besides olefin based mud and both stated when the thickness of sludge layer of sample inside microwave chamber increased the penetration of microwave takes longer time to achieve the drying process. For that reason, for concentration $12.5 \%$ and $15 \% \mathrm{w} / \mathrm{w}$ in mass in the first ten minute, the decreasing in concentrations is not like the concentration in $7.5 \%$ and $10 \% \mathrm{w} / \mathrm{w}$ in mass.

In spite of increasing the power applied in the microwave treatment to increase the speed of reducing hydrocarbon concentrations can only be economically useful till about 35-40 minutes as it's shown in Figs. 1, 2, 3 and 4 below that from 35-40 minutes until the time of the experiment reach the end of fifty minute the decreasing in oil contamination is relatively slow which is same result for Silva et al. (2019) but with synthetic- based mud and reaching less than $1 \%$ for most of their experiments. The study attributes the relative slow in decreasing of concentration in the last fifteen minutes to the residue of high-density compositions that remain after the evaporating of the light compositions in which the microwave has difficulty in treating them. Furthermore, even of such a difference in treatment a study needs to be done for larger different between the specific gravities. However, the range of specific gravities shows the regular type of crude oil that obtained from Iraqi oilfields and that will lead to a conclusion which is the difference in specific gravities does not affect directly on the concentration decreasing when the microwave is used for treating a drill cutting with oil (obtained from Iraqi reservoir) contamination. 


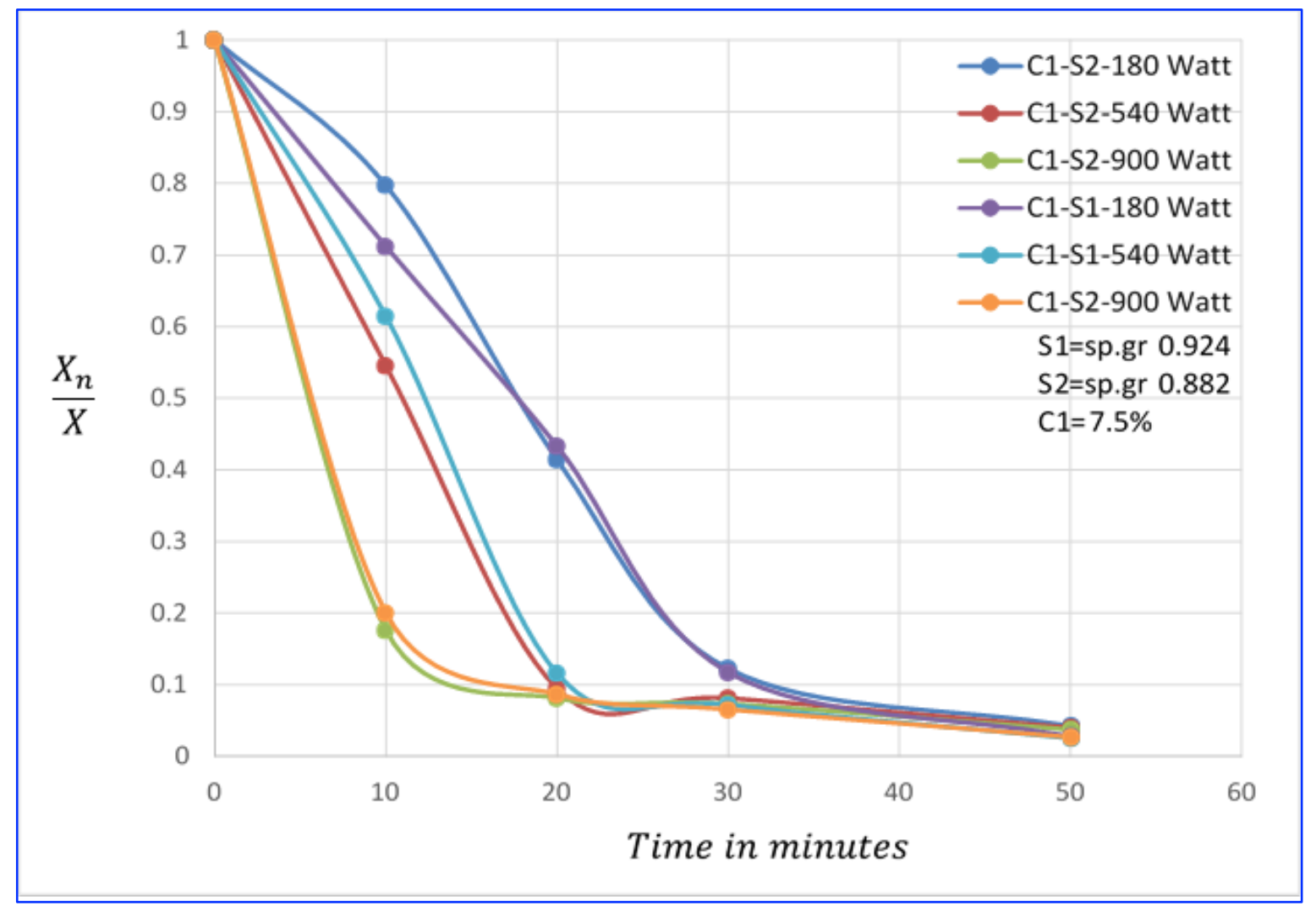

Fig. 1. Dropping in contamination ratio for initial of $7.5 \% \mathrm{w} / \mathrm{w}$ in mass with respect to time

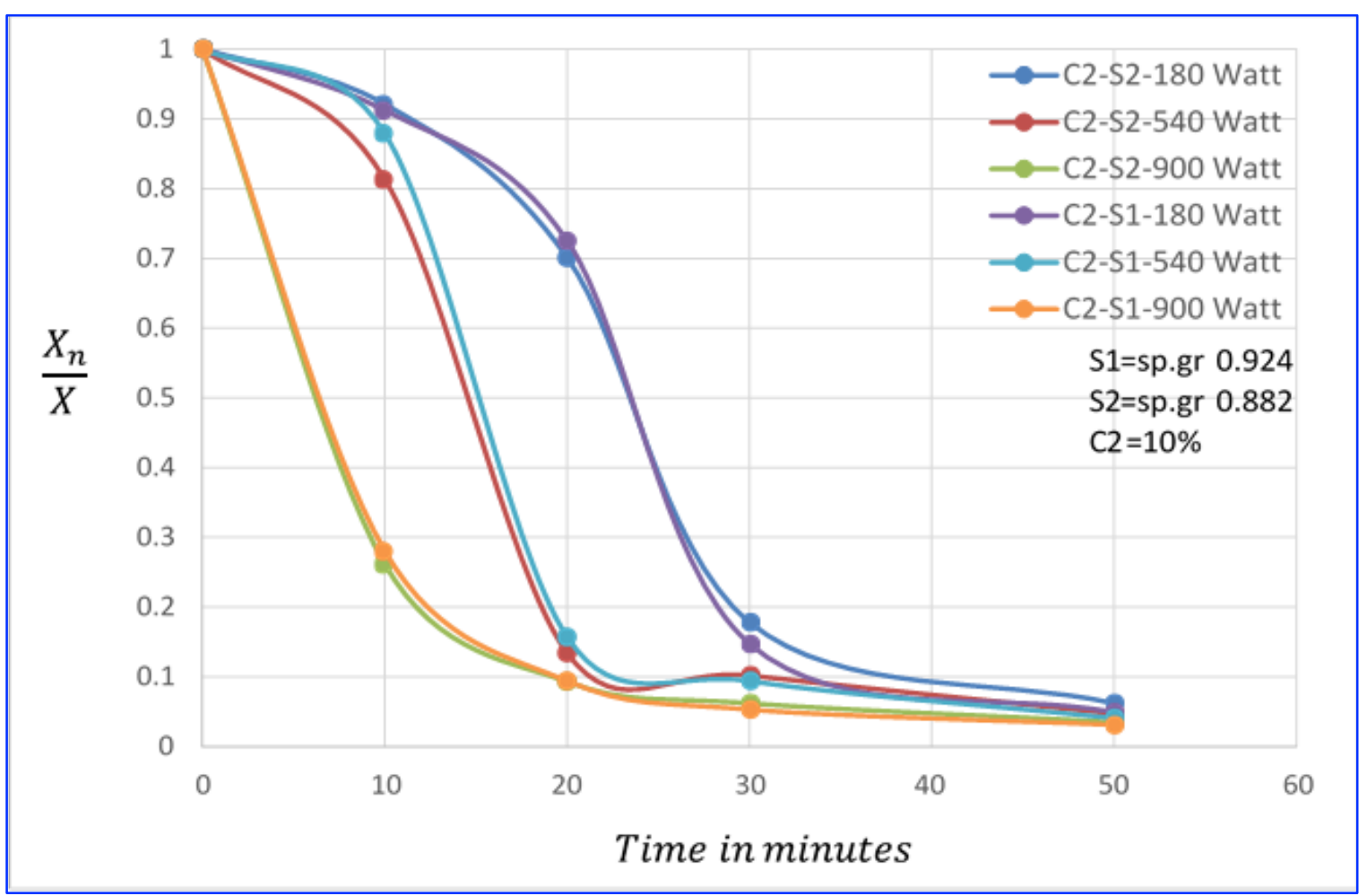

Fig. 2. Dropping in contamination ratio for initial of $10 \% \mathrm{w} / \mathrm{w}$ in mass with respect to time 


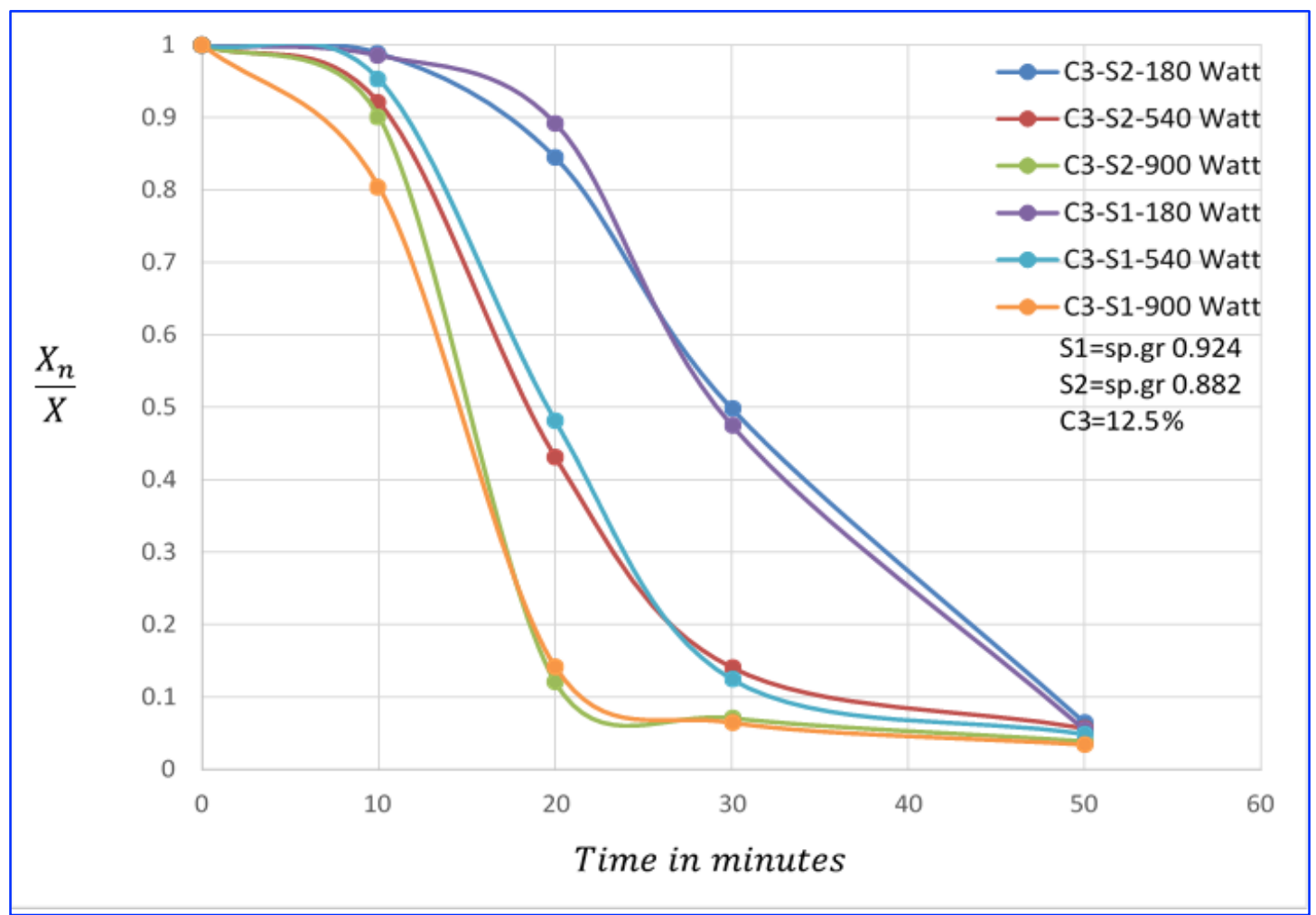

Fig. 3. Dropping in contamination ratio for initial of $12.5 \% \mathrm{w} / \mathrm{w}$ in mass with respect to time

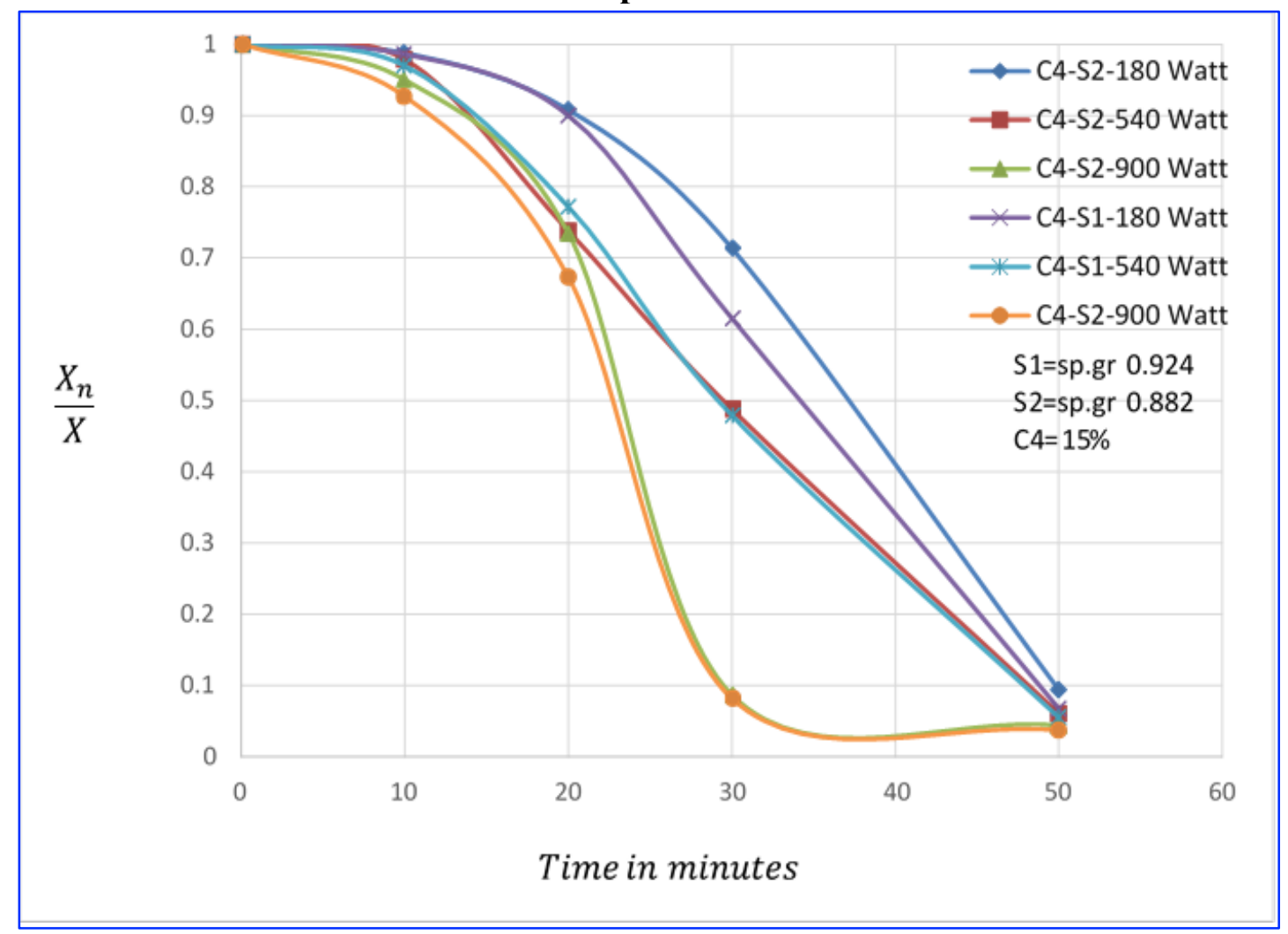

Fig. 4. Dropping in contamination ratio for initial of $15 \% \mathrm{w} / \mathrm{w}$ in mass with respect to time 


\section{CONCLUSIONS}

According to the experimental results, the main conclusions of the present study are:

1. The longer the period of time for treatment by microwave, the greater the efficiency of reducing pollution, especially with higher oil concentration.

2. The greater the power applied by microwave, the faster the hydrocarbon pollution will decrease, over time passage the slope begins to form the exponential inclination.

3. The application of microwave technique leads to a successful treatment for drill cuttings with different range in Sp. Gr. of oil contamination for Iraqi oilfields.

4. Governmental legislation must be developed to control and manage the disposal of drilling waste, especially in cases where oil-based drilling fluids are used.

\section{NOMENCLATURE}

Sp. Gr. = Specific gravity, Dimensionless.

$\mathrm{W}_{\mathrm{n}}=$ The remain weight of hydrocarbon after any period of time, gm.

$\mathrm{W}_{\text {hydi }}=$ The initial weight of hydrocarbon before treatment, gm.

$\mathrm{W}_{\text {con }}=$ weight of glass container, gm.

$\mathrm{W}_{c u t}=$ Weight of fixed drill cuttings, gm.

$\mathrm{W}_{t(n)}=$ The total weight at any period of hydrocarbon contamination, gm.

$\left(\frac{X_{n}}{X}\right)=$ The ratio of the oil contamination weight at any period to its initial where $\left(0 \leq \frac{X_{n}}{X} \leq 1\right)$ dimensionless.

\section{REFERENCES}

Abdulbari, H. A., Abdurahman, N. H., Rosli, Y. M., Mahmood, W. K., and Azhari, H. N., 2011. Demulsification of petroleum emulsions using microwave separation method. International Journal of Physical Sciences, 6(23): 5376-5382.

Al-Ali, R. A., Mahdi, M. M., and Mohammed, A. H., 2020. Biostratigraphy of Khasib Formation by using planktonic Foraminifera at selected wells in Rumila Oil Field, Southern Iraq. Iraqi Geological Journal, 53 (1D): 53-67.

Al-Jaberi, M. H., and Al-Mayyahi, H. K., 2018. Wireline logging response and true core analysis of the upper shale member of Zubair Formation, Rumaila Oilfield, Southern Iraq. Iraqi Geological Journal, 51 (2): 2840.

Appleton, T. J., Colder, R. I., Kingman, S. W., Lowndes, I. S., and Read, A. G., 2005. Microwave technology for energy-efficient processing of waste. Applied energy, 81(1): 85-113.

Chaineau, C. H., Morel, J. L., and Oudot, J., 1996. Land treatment of oil-based drill cuttings in an agricultural soil. Journal of Environmental Quality, 25(4): 858-867

Di Toro, D. M., Mcgrath, J. A., and Stubblefield, W. A., 2007. Predicting the toxicity of neat and weathered crude oil: toxic potential and the toxicity of saturated mixtures. Environmental Toxicology and Chemistry: An International Journal, 26(1): 24-36.

Fernandez, Y., Arenillas, A., and Menendez, J. A., 2011. Microwave Heating Applied to Pyrolysis. in S Grundas (Ed.), Advances in Induction and Microwave Heating of Mineral and Organic Materials, London, UK: Intechopen, 723-751. 
Growcock, F. B., Curtis, G. W., Hoxha, B., Brooks, W. S., and Candler, J. E., 2002. Designing invert drilling fluids to yield environmentally friendly drilled cuttings. In IADC/SPE Drilling Conference. Society of Petroleum Engineers.

Haghi, A. K., and Amanifard, N., 2008. Analysis of heat and mass transfer during microwave drying of food products, Brazilian Journal of Chemical Engineering, 25: 491-501.

Haut, R. C., Rogers, J. D., McDole, B. W., Burnett, D., and Olatubi, O., 2007. Minimizing Waste During Drilling Operations. In 2007 AADE National Technical Conference and Exhibition, Houston.

Hu, G., Li, J., and Zeng, G., 2013. Recent development in the treatment of oily sludge from petroleum industry: a review. Journal of hazardous materials, 261: 470-490.

Jafarinejad, S., 2017. Environmental impacts of the petroleum industry, protection options, and Regulations. Petroleum waste treatment and pollution control, 85-116.

Junior, I. P., Pereira, M. S., dos Santos, J. M., Duarte, C. R., Ataíde, C. H., and Panisset, C. M. D. Á., 2015. Microwave remediation of oil well drill cuttings. Journal of Petroleum Science and Engineering, 134: 23-29.

Kirkeleit, J., Riise, T., Bråtveit, M., and Moen, B. E., 2006. Benzene exposure on a crude oil production vessel. Annals of Occupational Hygiene, 50(2): 123-129.

Montagnolli, R. N., Lopes, P. R. M., and Bidoia, E. D., 2015. Screening the toxicity and biodegradability of petroleum hydrocarbons by a rapid colorimetric method. Archives of Environmental Contamination and Toxicology, 68(2): 342-353.

Moseley, H. R., 1983. Summary of API Onshore Drilling and Produced Water Environmental Studies. SPE.11398 Presented At IADC/SPE Drilling Conf. New Orleans.

Omran, M., Fabritius, T., Elmahdy, A. M., Abdel-Khalek, N. A., El-Aref, M., and Elmanawi, A. E. H., 2014. Effect of microwave pre-treatment on the magnetic properties of iron ore and its implications on magnetic separation. Separation and Purification Technology, 136: 223-232.

Prasad, M. S., and Kumari, K. 1987. Toxicity of crude oil to the survival of the fresh water fish Puntius Sophore (HAM.). Acta Hydrochimica Et Hydrobiologica, 15(1): 29-36.

Proestos, C., and Komaitis, M., 2008. Application of microwave-assisted extraction to the fast extraction of plant phenolic compounds. LWT-food science and technology, 41(4): 652-659.

Regier, M., Knoerzer, K., and Schubert, H. (Eds.)., 2016. The microwave processing of foods. Woodhead publishing.

Robinson, J. P., Kingman, S. W., Snape, C. E., Bradshaw, S. M., Bradley, M. S. A., Shang, H., and Barranco, R., 2010. Scale-up and design of a continuous microwave treatment system for the processing of oilcontaminated drill cuttings. Chemical Engineering Research and Design, 88(2): 146-154.

Robinson, J. P., Kingman, S. W., Snape, C. E., Barranco, R., Shang, H., Bradley, M. S. A., \& Bradshaw, S. M., 2009. Remediation of oil-contaminated drill cuttings using continuous microwave heating. Chemical Engineering Journal, 152(2-3): 458-463.

Santos, J. M., Petri, I. J., Mota, A. C. S., dos Santos Morais, A., and Ataíde, C. H., 2018. Optimization of the batch decontamination process of drill cuttings by microwave heating. Journal of Petroleum Science and Engineering, 163: 349-358.

Siddique, S., Kwoffie, L., Addae-Afoakwa, K., Yates, K., and Njuguna, J., 2017. Oil based drilling fluid waste: An overview on environmentally persistent pollutants. In IOP Conference 'Series: Materials Science and Engineering, 195 (1): 012008. IOP Publishing.

Silva Mota, A. C., Santos, J. M., Silva Rossi, A., Duarte, C. R., Pereira, M. S., and Ataíde, C. H., 2019. Dielectric properties and microwave drying kinetics of drill cuttings contaminated with synthetic drilling fluid. Drying Technology, 38(7): 940-951.

Tinmaz Köse, E., Çelen, S., and Çelik, S. Ö., 2019. Conventional and microwave drying of hydrocarbon cutting sludge. Environmental Progress \& Sustainable Energy, 38(4): 13104.

Ubani, E. C., and Onyejekwe, I. M., 2013. Environmental impact analyses of gas flaring in the Niger delta region of Nigeria. American journal of scientific and industrial research, 4(2): 246-252.

Zimmerman, P. K., and Robert, J. D., 1991. Oil-based drill cuttings treated by landfarming. Oil and Gas Journal; United States, 89(32). 